\title{
THE EVOLUTION OF ISIS IN INDONESIA WITH REGARDS TO ITS SOCIAL MEDIA STRATEGY
}

\author{
Naufal Armia Arifin \\ Politic Activist \\ naufalarmia.a@gmail.com
}

\begin{abstract}
ISIS is a splinter terrorist group from Al-Qaeda that became a global threat in the last two decades. Its recruitment method that is different from its predecessor, also how it utilizes social media effectively, made them able to spread terror to every part of the world and conquer many territories of Iraq and Syria in order to fulfill their goal of a caliphate. However, recent development shows ISIS will lose their base of operation in both countries and there are signs of ISIS shifting their focus to Southeast Asia, with regards to the Marawi conquest. This paper aims to discuss how such development affects ISIS in Indonesia as the largest Muslim country in Southeast Asia and how the government responds to the situation.
\end{abstract}

Keywords: isis; al-qaeda; social media; foreign fighters; indonesia.

\section{Abstrak}

ISIS adalah kelompok teroris pecahan dari Al-Qaeda yang menjadi ancaman global dalam hampir dua dekade terakhir. Metode perekrutan anggota ISIS yang berbeda dari pendahulunya, serta bagaimana ISIS memanfaatkan sosial media dengan efektif membuat kelompok ini dapat menyebarkan teror di seluruh dunia dan menguasai banyak wilayah di Irak dan Suriah untuk memenuhi tujuan negara kekhalifahan mereka. Namun, perkembangan terkini menunjukkan ISIS akan kehilangan basis operasinya di kedua negara tersebut dan terdapat tanda bahwa ISIS akan mengalihkan fokus mereka ke Asia Tenggara dengan berkaca pada peristiwa penaklukan Marawi. Tulisan ini bertujuan untuk mendiskusikan bagaimana perkembangan tersebut berpengaruh pada ISIS di Indonesia sebagai negara Muslim terbesar di Asia Tenggara dan bagaimana pemerintah meresponnya.

Kata Kunci: isis; al-qaeda; media sosial; pejuang asing; indonesia.

\section{Introduction}

Terrorism has evolved from acts of terror with political motives related to civil wars, struggle of independence, etc to a representation of clash between civilizations, with the focus of the West against Islam, especially in the last decade. What grew from Afghanistan struggle against the Soviet Union's Invasion in the 1980s was a bloom of terrorist organizations that believes the narrative that western countries are a threat to Islam, and therefore must be retaliated in a holy war or Jihad. The turning point is the 9/11 attack on the United States by Al-Qaeda, it has redefined the focus of terrorism and have created a "global war on terror" era.

With the invasion of Afghanistan and Iraq, the threat of Al-Qaeda has waned after years have passed. However, it has taken a new form in the name of Islamic State in Iraq and
Syria (ISIS), and the technological advancement of internet have also enhanced how ISIS conduct its attacks, recruit more members, and expand its influence globally. With regards to social media, ISIS has the potential to radicalize every individual that have access to the internet. ISIS can also coordinate its attack with peer to peer messaging applications, an evolution from AlQaeda's use of internet for spreading propaganda only. The implication of such requires all governments that are committed to the global war on terror to adapt their strategy that includes the use of internet and social media.

The underlying threat of ISIS utilizing the social media is the increase of unpredictability whether when, where and who will spread terror, thus increasing the threat level. It also suggests that the spread of 
propaganda material will be harder to contain as information can be relayed rapidly and with discreet. This essay aims to analyze the current implication and will divide the essay with the following outline: First it will discuss the history of ISIS and its difference with AlQaeda, how ISIS then evolved using social media to coordinate attacks and spread its influence in the West, its group current condition, and lastly, the shift of focus to Southeast Asia particularly Indonesia with regards to how the government address the situation.

\section{ISIS and Al-Qaeda, the Difference}

The creation of ISIS dates back from remnants of Al-Qaeda in Iraq (AQI) post U.S Invasion to Iraq, where Abu Musab al Zarqawi, born from Jordan joined Afghanistan's conflict against the Soviet Union in 1989. He operated from Peshawar, a Pakistani border known as one of the source of Islamic radicalism. From there he developed his fundamentalist Salafist faith, an ideology branch from Sunni Islam, and hatred towards Shiite and moderate Muslims. It was also suspected that Zarqawi met with Osama bin Laden for the first time, but the two have different mission whereas Osama bin Laden insist in inciting a global holy war against U.S and the West, Zarqawi then led his war to Israel and Jordan. ${ }^{1}$ At that time the group that Zarqawi formed was called the Al-Tawhid wal-Jihad (TwJ), backed by the Taliban movement to counter against the U.S Invasion of Afghanistan in 2001.

Zarqawi, having increased his network of terrorist contacts and rising through the ranks have made himself a high-profile target and was forced to move between Iran, Syria, Lebanon, and the Kurdish-controlled areas of

\footnotetext{
${ }^{1}$ M.J Kirdar "Al Qaeda in Iraq", CSIS, June 2011, accessed 8 July 2017, https://csisprod.s3.amazonaws.com/s3fspublic/legacy_files/files/publication/110614_Kirdar _AlQaedaIraq_Web.pdf.Pg. 3.
}

Northern Iraq. ${ }^{2} \mathrm{He}$ was still in contact with $\mathrm{Al}-$ Qaeda through Seif al-Adel, Osama's Security Chief that favored Zarqawi's mission against the nearer enemy (Israel and Jordan). Adel eventually managed to convince Zarqawi to transfer to Iraq, and in the country Zarqawi frequently travelled to the "Sunni Triangle" a 100-square mile area between Baghdad, Ramadi, and Tikrit where he further developed his network and presence, eventually taking an elevated role as a conduit for all foreign fighters coming to Iraq in preparation for the U.S Invasion. ${ }^{3}$

As the Invasion takes place in 2003, Zarqawi had already prepared the necessary strategies to counter the invading force, most notably entangling U.S forces with a SunniShiite civil war through attacking Shiite targets and provoking retaliatory responses against Sunni communities. ${ }^{4}$ A year later, Zarqawi was proclaimed as the Emir of the "Islamic caliphate (state) in Al-Fallujah" and he declared his allegiance to Osama bin Laden, transforming TwJ into Al-Qaeda in Iraq $(\mathrm{AQI}){ }^{5}$

Backlash against Zarqawi's popularity begin in 2005 where the national elections resulted in tensions between factions in the insurgency, Zarqawi's tactic of targeting Shiites and suicide bombings that affects innocent Muslims have made nationalists in the faction distanced themselves from Zarqawi. Eventually it reached its peak when AQI's bombings in Jordan's Amman hotel killed 60 innocents, inciting a demonstration in the streets. ${ }^{6}$ A year later, after attempts to lower the backlash by the public, Zarqawi was kill by a U.S Airstrike.

The death of Zarqawi does not hinder AQI' brutal method in their operations, resulting in a retaliatory response where Sunni tribesman were infuriated with AQI attempting

\footnotetext{
${ }^{2}$ Ibid, pg. 3. accessed 8 July 2017

${ }^{3}$ Ibid, pg.3. accessed 8 July 2017

${ }^{4}$ Ibid, pg. 4. accessed 8 July 2017

${ }^{5}$ Ibid, pg. 4. accessed 8 July 2017

${ }^{6}$ Ibid, pg. 4. accessed 8 July 2017
} 
to take over their territory, AQI's effort to reduce the impact of this backlash were to rebrand itself with the creation of Islamic State in Iraq (ISI). The backlash reduced the number of IS fighters in Iraq significantly, until Prime Minister Nouri Al-Maliki of Iraq arrested Sunni political leaders and gave Shia tribes disproportionate benefits which resulted in increased sectarian conflict leading to ISI gathering support from Sunni tribes again. ${ }^{7}$ A year later, Abu Bakr Al-Baghdadi became the leader of ISI and expanded the presence of the terrorist group to Syria through the Nusra Front group in 2012.

\section{How ISIS Became a Western Threat}

As the popularity of Al-Qaeda dwindled down after the 9/11 attack and U.S Invasion to Afghanistan, ISIS appeared to replace Al-Qaeda as the most dangerous terrorist group in the world. One of the factors that contribute to the phenomena is how ISIS's method of recruiting foreign fighters differs from Al-Qaeda. After 9/11, we see a multinational effort led by the U.S to engage terrorism on a global scale. National security was top priority to prevent such event to occur again, and it was harder for Al-Qaeda to develop its terrorist cells in western territories. From this point on, the concept of foreign fighters of terrorist groups plays an important role in emphasizing ISIS as a global threat.

Of course, the role of foreign fighters is not exclusive for ISIS only, but what made it different are the countries where ISIS recruited their fighters. Even though Al-Qaeda's scope of target is broader than ISIS they were only able to recruit the majority of their foreign fighters from countries surrounding Saudi Arabia such as Jordan, Tunisia, Yemen, and Libya. $^{8}$ The background of these foreign

\footnotetext{
7 Zachary Laub, "The Islamic State", Council on Foreign Relations, last updated 10 August 2016, $\begin{array}{llll}\text { accessed } & 11 & \text { July } & \text { 2017, }\end{array}$ https://www.cfr.org/backgrounder/islamic-state.

${ }^{8}$ Tony Cartalucci, "NATO Using Al Qaeda "Rat Lines" to Flood Syria With Foreign Terrorists",
}

fighters is generally from well-respected families with college education, and although they received prior training in Afghanistan, the western theatre will be the first real combat experience for most of them. ${ }^{9}$ Al-Qaeda is losing their strength with the death of Osama bin-Laden in 2011 and constant drone airstrikes that forced their top leaders into hiding. With a command structure that relied heavily on top-down communication it was significantly difficult for the group to continue its operations outside its own border. ${ }^{10}$

On the other hand, ISIS can attract individuals from western countries to come to Iraq or Syria and send them back to their home country with much ease. ISIS recruited their fighters without considering if they came from a well-educated background or not, took in volunteers with criminal records such as car hijacking and bank robbery and give them a new sense of purpose. ${ }^{11}$ When they return to their home country, there will risk of being tracked by screening measures from government authorities, but the overwhelming number of have made their travel as easy as using only their passports. ${ }^{12}$

ISIS related incidents in the West have greater impact than Al-Qaeda's. First, these foreign fighters have returned to their respective neighborhoods which gave the advantage of minimal security problems and they can conduct their operations on familiar

Global Research last modified 26 October 2012, $\begin{array}{llll}\text { accessed } & 11 & \text { July } & 2017\end{array}$ http://www.globalresearch.ca/nato-using-al-qaedarat-lines-to-flood-syria-with-foreignterrorists/5309573

9 Clint Watts, "Why ISIS Beats al Qaeda in Europe", Foreign Affairs, last modified 4 April 2016, accessed $11 \quad$ July 2017 https://www.foreignaffairs.com/articles/2016-0404/why-isis-beats-al-qaeda-europe

${ }^{10}$ Clint Watts, “Al Qaeda Loses Touch”, Foreign Affairs, last modified 4 February 2015, accessed 11 July 2017 https://www.foreignaffairs.com/articles/middleeast/2015-02-04/al-qaeda-loses-touch

${ }^{11}$ Ibid.

${ }^{12}$ Op Cit. 
grounds. Second, they often have strong relations with each other as life-long friends that returned from ISIS's training together, and since most have previous criminal records they are not troubled taking such activities even further. Lastly, ISIS differs from Al-Qaeda's top-down structure and fits the more clandestine/ terrorist cell structure perfectly. ${ }^{13}$ Its foreign fighters are tightly-knitted and able to operate autonomously, unlike Al-Qaeda's command structure which required frequent communication that can be traced, ISIS terrorist cells can prepare and execute their plan with less risk of being found-out.

\section{ISIS Empowered Through Social Media}

The advancement of internet and the world wide web contributes a significant part to how ISIS spread its propaganda of terror, and how it even uses the social media as a recruitment tool for foreign fighters. This part of the essay will discuss how ISIS utilize social media to inspire and even radicalize supporters that even never had combat training or travelled to Iraq and Syria, and present one case study that happened in the U.S.

It should be noted first that Al-Qaeda pioneered the use of internet to spread its message, it even has its own in-house production team named Al-Sahab that produced video about their leaders, images of battles with Al-Qaeda members, and other messages intended to gain appeal for the public in Middle Eastern countries. ${ }^{14}$ These materials were then spread to forums or groups that sympathized with Al-Qaeda to be individually emailed, the individuals that have joined the mailing list are then given a link that led them

13 Clint Watts, "Why ISIS Beats al Qaeda in Europe", Foreign Affairs, last modified 4 April 2016, accessed $11 \quad$ July 2017 https://www.foreignaffairs.com/articles/2016-0404/why-isis-beats-al-qaeda-europe

14 Hassan M. Fattah, "Al Qaeda Increasingly Reliant on Media", New York Times, last modified 30 April 2006, accessed 15 July 2017 http://www.nytimes.com/2006/09/30/world/30jorda n.html to an encrypted website, where they can gather the propaganda materials and spread them discreetly. ${ }^{15}$ Furthermore, the videos that were circulated around are not always depiction of call to arms that arouse people to join, but in a form of scholarly preaches to appeal to a broader array of citizens as well.

First is the principle of both group in how it spread its propaganda, similar to how ISIS does not concern itself with methodical approach in recruiting its foreign fighters, the group likewise boast openness and even crowdsourcing with netizens without concerns of the individual's background. ISIS does not worry itself with encrypted messages or password-protected websites that only a few carefully selected sympathizers can access, but instead spread around its ideology akin to an open-source material that anyone can use. ${ }^{16}$ This open source material attracted people with unstable mental conditions, those who feel desperate and deluded can construct their own narrative of channeling their inner rage towards their society. If the goal of spreading terror is achieved, it is not a problem for ISIS.

Take for example the 2015's San Bernardo Shooting that killed fourteen people in South California, U.S. It was unthinkable that the two perpetrators would be a husband and wife that were U.S citizens, and when investigated further close relatives of the family were shocked and unaware the married couple were radicalized. Syed Ridwan Farook was born in Illinois and raised in California, the husband met his wife through an online dating service in Saudi Arabia. While Tashfeen Malik was born in Pakistan and raised in Saudi Arabia, but eventually acquired legal

\footnotetext{
${ }^{15}$ Ibid.

${ }^{16}$ Brendan I. Koerner, "Why ISIS Is Winning the Social Media War", WIRED, last modified April 2016, accessed $15 \quad$ July 2017 https://www.wired.com/2016/03/isis-winningsocial-media-war-heres-beat/\#slide-x
} 
permanent status in the States. ${ }^{17}$ The Federal Bureau of Investigation (FBI) presumed that the couple were radicalized through the internet. ${ }^{18}$ As the fact shown they did not return to Saudi Arabia nor Pakistan after their marriage, it was further presumed that Malik was already radicalized prior to living in the U.S and influenced her husband afterwards. Before the shooting begun, it was described that the couple swore their allegiance to ISIS through posting on Facebook (FB). ${ }^{19}$ Both were killed in a shootout against the police, authorities then found the couple original plan of using bombs strapped to a remote-controlled toy in the scene of the massacre in the SUV used for the attack. ${ }^{20}$ Additional investigation unraveled there were traces of digital footprint being erased from their computer and cellphones being destroyed, and a makeshift bomb lab was found in their house.

Later ISIS praised the couple as supporters who were martyred for their cause. As far as including their story in their monthly magazine titled Dabiq, and even justifying the husband and wife decision to leave behind their daughter by referencing excerpts from the Holy Quran. ${ }^{21}$ The magazine itself can be considered professional work, structured neatly imitating real magazines with foreword, headline story, topic of the month, selected videos to watch, and so forth. It is well-written in English language and can be misleading to those who did not understand Islam bound to be radicalized.

From this case study, we can infer even though there are no further reports whether Farook and Malik were radicalized by

17 Faith Karimi, "San Bernardino shooters 'supporters' of ISIS, terror group says", $C N N$, last modified 6 December 2015, accessed 15 July 2017 http://edition.cnn.com/2015/12/05/us/san-

bernardino-shooting/index.html

${ }^{18}$ Ibid.

${ }^{19}$ Ibid.

${ }^{20}$ Ibid.

${ }^{21}$ "Dabiq, $13^{\text {th }}$ Issue", last modified 2015, http://clarionproject.org/factsheets-files/Issue-13the-rafidah.pdf
ISIS through social media, the evidence and turn of events fit seamlessly with ISIS's social media strategies. The link that can be deducted start with how the couple were U.S citizens that never travelled to ISIS strongholds in Iraq or Syria and never received any combat training from ISIS members as well. From the story we know that, Malik was radicalized prior to marrying Farook and started influencing his husband after they settled back in the U.S, most likely the radicalization process continued online. This deduction can be further emphasized with how they pledge their allegiance to ISIS through their Facebook account before the incident occurred and how authorities found digital footprints in their house that could very well be linked to ISIS.

Another social media strategy that ISIS use is peer to peer messaging app such as Telegram. While there are many similar app to choose from, ISIS particularly uses Telegram for its privacy policy that enables it to send encrypted messages in large format up to 1 GB. The large format enables them to send video instructions of how to make bombs from everyday utensils or coordinate attacks in a more detailed manner. The $13^{\text {th }}$ November 2015 in France was orchestrated by ISIS with the use of Telegram, they could conduct a simultaneous attack on various public location which was a concert hall, a stadium, restaurants and bars, resulting in 130 casualties. $^{22}$ Unlike Al-Qaeda's attack on Charlie Hebdo's Magazine earlier in January, ISIS did not target places or group that has ideological implications on it. The magazine in France was known to produce satirical illustrations that offended many, including depiction of Prophet Muhammad which is strictly forbidden in Islam. This had led AlQaeda to plan the attack for years and claim it

\footnotetext{
${ }^{22}$ Rowan Scarborough, "Islamic State using app to broadcast terror instructions, propaganda", Washington Times, last modified January 82017 , $\begin{array}{llll}\text { accessed } & 18 & \text { July } & 2017\end{array}$ http://www.washingtontimes.com/news/2017/jan/8/ isis-using-telegram-app-to-broadcast-terror-instru/
} 
as a 'revenge for honor' because of Charlie Hebdo's inappropriate depiction. ${ }^{23}$

From had been gathered up to now, ISIS is considerably different than its predecessor Al-Qaeda in terms of ideology and strategies. While Al-Qaeda is focused on the narrative of fighting the West and depict them as a threat to Islam, ISIS expand it further by creating an Islamic caliphate as its main goal and fighting the West that gets in the way. In terms of strategy, we know that Al-Qaeda prefer a methodical approach in creating terror in western countries, and it even spread its propaganda carefully as to make sure the source is not traced back. On the other hand, ISIS embrace openness for its ideology to be crowdsourced for anyone that wants to craft their own individual narrative with ISIS branding. The result was they would be able to recruit more foreign fighters from western countries, encourage individuals that are nonaffiliated to be lone wolf attackers, and claim the result of the attack for themselves, increasing their unpredictability and threat level.

\section{ISIS Current Condition}

True to its goals of creating a caliphate based on its own perspective of Islam, ISIS has achieved more than just creating a reign of terror. Since 2014, the terrorist group has controlled massive territories and strategic point in both Iraq and Syria, creating its own government inside those controlled territories, imposing its own sharia laws, and inspired other jihadist groups from different continent to pledge their allegiance and do the same. The first to be captured was the city of Raqqa in northern Syria, it was the first major city captured by ISIS. From that point on it had captured Mosul (the second largest city of

\footnotetext{
${ }^{23}$ Karl Vick, “Al-Qaeda Group Claims Responsibility for Paris Terror Attack",TIME, last modified 10 January 2015, accessed 18 July 2017 http://time.com/3661650/charlie-hebdo-paris-terrorattack-al-qaeda/
}

Iraq) and another city called Tikrit, conquering a large section of northern Iraq that links to east of Syria from the city of Raqqa to Deir ezZor. ${ }^{24}$ It was by this time, ISIS had officially declared its caliphate.

Despite its advancement of both Iraq and Syria, ISIS gained territories that were far too outstretched to be well-defended. And, ISIS did not just face the U.S and its international coalition forces but opposing Shi' a tribes notably Kurdish minorities as well. Two years after declaring its caliphate ISIS had suffered major losses in both Syria and Iraq. U.S backed alliance of Arab and Kurdish fighters are besieging the town of Raqqa while on July $10^{\text {th }}$ this year Iraqi government forces have declared the city of Mosul to be liberated from ISIS. ${ }^{25}$ While many would see the turn of events as a positive progress in the war against terrorism, scholars and policy makers alike are concerned of the underlying threat after the caliphate crumbles. The scenario of mass exodus of ISIS fighters to other countries and even the possibility of ISIS relocating their strongholds.

\section{Marawi, a Narrative for a New Caliphate}

Thus, earlier in May this year, the world was caught in surprise as ISIS captured the city of Marawi in Mindanao, Philippines and raised the regional awareness of terrorist threats to new heights. The island of Mindanao which was eventually under the state of Martial Law was historically known to house several terrorist group that has different motives and level of threat to the government. Such as the Moro Islamic Liberation Front (MILF) that started more than three decades of

\footnotetext{
${ }^{24}$ Pamela Engel, "This map shows how much territory ISIS has lost this year", Business Insider, last modified 21 December 2015, accessed 18 July 2017, http://www.businessinsider.sg/map-howmuch-territory-isis-lost-2015-12/?r=US\&IR=T .

${ }^{25}$ BBC News, "Islamic State and the crisis in Iraq and Syria in maps", $B B C$, last modified January 2016, accessed $18 \quad$ July 2017 http://www.bbc.com/news/world-middle-east27838034
} 
rebellion against the government for a more autonomous rule of Mindanao and Muslim Moro minorities, the group had reached a positive progress with the government where in 2014 the peace treaty of "Comprehensive Agreement on the Bangsamoro" was signed. ${ }^{26}$ The same year was the start of ISIS's spread of influence in the country with the help of social media.

The Institute of Policy Analysis on Conflict (IPAC) retraced the presence of ISIS from the start of May 2014, where a video showed Nine Filipinos swearing their allegiance to Al-Baghdadi in Arabic, then finishing the speech in Tagalog. IPAC also assumed Indonesians were involved, seeing how the opening credits showed a stamp written in Bahasa Indonesia. ${ }^{27}$ The series of events afterward included various pledges from different terrorist factions in Mindanao and eventually formed the coalition of 'Daulah Islamiyah Wilayatul Mashriq' or IS - East Asia Region. Furthermore, fast forward to the first few days of the clashes between Government forces and ISIS, the Telegram app played an important role in spreading the news of the captured city and inviting other extremists to join the fight. Telegram was also used to spread around the message that supporters of terrorist groups in the country to start referring the terrorist faction as Junudul Khifalah (soldiers of the state), IS fighters, IS of East Asia, it was specifically ordered by ISIS in Iraq and Syria to refrain the use of

\footnotetext{
${ }^{26}$ Agence France-Presse, "Timeline: Moro history in the southern Philippines", $A B S-C B N$, last modified 28 March 2014, accessed 20 July 2017 http://news.abs-

cbn.com/nation/regions/03/27/14/timeline-morohistory-southern-philippines.

27 Institute for Policy Analysis of Conflict, "MARAWI, THE "EAST ASIA WILAYAH" AND INDONESIA", last modified 21 July 2017 , $\begin{array}{llll}\text { accessed } & 26 & \text { July } & 2017\end{array}$ http://file.understandingconflict.org/file/2017/07/IP AC_Report_38.pdf, Pg. 2.
}

terms that shows ethnical, regional, or national difference. ${ }^{28}$

This recent turn of event implicitly showed how much impact the use of ISIS's narrative can make, regarding viewing it as a crowdsource material. It can be very well perceived as a brand, much like attaching a sponsorship logo to a racing car to boost its profile. Take the specific case of Isnilon Hapilon, a former Abu Sayaff terrorist faction that was wounded in battle with Philippines government forces, declared his allegiance and was proclaimed as the "Emir" of ISIS in East Asia. Or Omar and Abdullah Maute, two brothers who were educated in Al-Azhar University of Egypt and Abdullah University in Jordan, they pledged their allegiance and cleverly used their strong family connections with MILF to acquire the necessary resources and funding. ${ }^{29}$ The use of ISIS as brand had even attracted MILF fighters who were disappointed with the peace negotiation progress with the government. The unpreceded event lead to MILF leaning to the government of Philippines in order to contain ISIS, where Mohagher Iqbal - Chief Negotiator of MILF said the group is willing to take an active role to put an end to the fighting in Marawi with greater regards in civilian interest. ${ }^{30}$

\section{ISIS In Indonesia: Past And Present}

Retracing back to early 2000 in Indonesia, the country with the highest number of Muslim population. This section will compare Al-Qaeda's presence in Indonesia with ISIS, how does ISIS maneuver in its earliest role and how will the Marawi incident

\footnotetext{
${ }^{28}$ Ibid. Pg. 8.

29 Jonathan Head, "Maute rebel group: A rising threat to Philippines", last modified 31 May 2017, $\begin{array}{llll}\text { accessed } & 27 & \text { July } & 2017\end{array}$ http://www.bbc.com/news/world-asia-40103602 30 Ryan Rosauro, "MILF willing to help end Marawi crisis", last modified 28 June 2017 , accessed $27 \quad$ July 2017 , http://newsinfo.inquirer.net/909394/milf-willing-toplay-role-to-resolve-marawi-crisis-if
} 
affects it? With regards to how ISIS employed its social media propaganda strategy as explained in the previous part of the essay.

The presence of Al-Qaeda in the country can be recognized by Jemaah Islamiah (JI) as the group's representative. JI was the perpetrators for the devastating Bali Bombing I \& II that took the lives of many foreign citizens, the J.W Marriot Hotel bombings, and the Australian Embassy bombing. From the location and casualties, Jemaah Islamiah is following Al-Qaeda's narrative in fighting against western countries as non-believers.

At this period, Jemaah Islamiah members were recruited from religious schools or madrasah that share the same radical values. These radicalized students who developed a narrow perspective of Muslim against non-Muslim world would then only interact with each other forming a 'beehive' of friendship and cooperation that are highly hostile against others that have different values. ${ }^{31}$ For example, most JI members who were involved in the Bali Bombings once attended the same madrasah or are associated with students of the place. $^{32}$ These incubators for radical extremist also appeared in Malaysia, creating a network of radical hotspots in Southeast Asia.

The pattern that appeared was in correlation with how Al-Qaeda in Afghanistan would operate, their network grows in a limited manner of like-minded individuals, and they would operate methodically with interval of a few years before another bombing attack was commenced, furthermore the hotspots also helps the authorities to monitor the spread and flow of extremists. But that pattern did not stay long as the influence of Al-Qaeda in Southeast Asia wane during a decade. In 2014 Abu Bakar Bashir as the leader of JI pledged his loyalty to ISIS, this event has increased the underlying

\footnotetext{
${ }^{31}$ Scott Atran, "The Role of Radical Madrasahs in Terrorism: The Indonesian Case", in Conflict, Community, and Criminality in Southeast Asia and Australia, ed. Arnaud De Borchgrave et, al, (Washington: CSIS, 2009), pg. 19.

${ }^{32}$ Ibid.
}

terrorism threat level in Indonesia significantly as ISIS now can not only manipulate individuals to be potential attackers, but have a rooster of madrasah grown extremists in their disposal as well.

From here on, the sequence of bombing attacks changed considerably whether from the perpetrators, targets, and modus operandi. Starting from the Sarinah Starbucks Bombing in Jakarta, 14 January 2016. The mastermind of this attack was Bahrun Naim, a University of Solo graduate with an Information Technology (IT) degree and worked as a computer technician. He was locally radicalized before joining IS in Raqqa, $2014 .^{33}$ The suicide bombing targeted a police post placed in a middle of a large road intersection, but killed four civilians instead. It was reported that Bahrun Naim coordinated the attack using Telegram after his other social media accounts were suspended while he was still in Syria. ${ }^{34}$ Additionally, in the end of 2016, the police force has foiled a terrorist plot that includes a pressure cooker bomb and a female would be suicide bomber. They were planning to attack a ceremony taking place in the Presidential Palace, choosing Sunday as there would be many family bystanders attending the event. ${ }^{35}$ Further investigation by

\footnotetext{
33 Sandy Indra Pertama, "Tentang Bahrun Naim yang Diduga Sosok Pengendali", CNN Indonesia, last modified 14 January 2016, accessed 27 July 2017, https://www.cnnindonesia.com/nasional/201601141 91812-12-104414/tentang-bahrun-naim-yangdiduga-sosok-pengendali/

34 Gadi Markitan, Arkhelaus Wisnu," Begini Bachrun Naim Manfaatkan Telegram Untuk Merancang Teror", Tempo.co, last modified 15 July 2017, accessed 27 Jul. 17 , "https://nasional.tempo.co/read/news/2017/07/15/0 63891613/begini-bachrun-naim-manfaatkantelegram-untuk-merancang-teror

35 The Associated Press, "Indonesian Police Arrest 4 Near Jakarta as Terrorist Plot Is Foiled", New York Times, last modified 10 December 2016, $\begin{array}{llll}\text { accessed } & 27 & \text { Jul } & 2017\end{array}$ https://www.nytimes.com/2016/12/10/world/asia/in donesian-police-arrest-4-near-jakarta-as-terroristplot-is-foiled.html
} 
the police showed the attackers linked to Bahrun Naim.

The year 2017 also saw two incidents involving the same bomb and attackers linked to ISIS. On February 27th an explosion occurred in Pandawa park, Bandung. Unfortunately, there were no casualties, and further investigation by the police shows how one of the attackers named Yayat Chadiyat was linked to Bahrun Naim again. He was previously arrested in 2012 with charges of providing illegal firearm and ammunition to the mastermind of Sarinah Bombing prior when Naim was still living in SoloPurwakarta. ${ }^{36}$ To conclude, along the span of one year there were already new forms of lone wolf attacks coordinated by a fellow Indonesian extremist from Syria. With the use of one peer to peer app that can send encrypted messages in large format, Bahrun Naim used Telegram to inspire his fellow extremists to create homemade bombs and attack two major cities in Indonesia.

The evolution of ISIS radicalization through social media doesn't just appeal to Indonesian males only. Based on an article written by an IPAC researcher there is a new phenomenon of migrant maids and nannies in Hongkong, Taiwan, and Singapore radicalized through social media at a small but alarming rate. ${ }^{37}$ The researcher interviewed a radicalized Indonesian maid with the pseudonym name of Ayu - aged 34 - who also is the head of ISIS supporters network in Hong Kong. She left for Hong Kong in 2003 to run away from abusive

\footnotetext{
${ }^{36}$ Rezki Alvionitasari, Imam Hamdi, Dewi Suci, "Police Clamps Down on Terror Ring Linked to Bandung Bomber", Tempo.co, last modified 1 March, accessed 27 July 2017, https://en.tempo.co/read/news/2017/03/01/0558513 50/Police-Clamps-Down-on-Terror-Ring-Linkedto-Bandung-Bomber

${ }^{37}$ Nava Nuraniyah, "Migrant Maids and Nannies for Jihad", New York Times, last modified 18 July 2017, , accessed $27 \quad 2017$ https://mobile.nytimes.com/2017/07/18/opinion/isis -jihad-indonesia-migrant-workers.html?smid=twshare\&referer $=$ https $\% 3 \mathrm{~A} \% 2 \mathrm{~F} \% 2 \mathrm{Ft} . \mathrm{co} \% 2 \mathrm{~F} 2 \mathrm{mysbb}$ $3 \mathrm{P} 4 \mathrm{~K}$
}

in-laws and succumbed to alcohol and drugs to numb depression. Eight years later after consequently losing her job as a maid for the third time, she went to Macau and lived on the streets for some time.

From there, she started to surf the internet looking for Islamic websites, looking for a spiritual refuge. But instead she was caught by the news happening in Syria and started befriending jihadists from social media. Ayu then returned to Hong Kong to join a Salafist Institute that was run by a nonextremist, she was reported by her teacher because of her vocal support of ISIS and left in 2014. She started translating propaganda materials from English to Indonesian for ISIS, spreading it through Twitter and Telegram. Eventually marrying an Indonesian Jihadist and introduced to the inner circles of Indonesian pro ISIS groups.

The article then stated that from combined reports of IPAC and the Indonesian police force from 500.000 Indonesian migrant worker who worked in the three countries stated before, there are about 45 who actively support ISIS. As said, it is a small number but to relate to the previous incident of the foiled bombing plan, it is possible that the female would be suicide bomber has similar background such as the story of Ayu. It is also concerning that these maids are more resourceful than most Indonesian ISIS supporters as they can establish international connection and have better English language. In Hong Kong, radicalized maids like Ayu would then congregate in Islamic study circles known as pengajian.

\section{Indonesia's Response TO The Growing Threat}

There are three responses by the government of Indonesia that the writer will discuss. First, eleven Telegram domains had been blocked in Indonesia, second the involvement of religious clerics from NU and Muhammadiyah organization in the 
deradicalization process, and third the ban of civil organization that are deemed as a threat to national security. As we know, over the case studies described, ISIS favored Telegram app as its main media of communication, the impact alone had been tremendous as one person such as Bahrun Naim can be a mastermind to two terror related incidents in Jakarta and Bandung. While, U.S and Europe had pleaded the creator of Telegram to block domains that were related to terrorists, the effort had been in disdain as only 78 channels were closed off out of hundreds of thousands. The creator insisted that it cannot close off all channel to guarantee the freedom of expression. ${ }^{38}$ Although it may seem like a quick solution for the government to block the main app that ISIS use for communication, many analysts agreed that it will be a pointless effort as ISIS can easily outmaneuver to a different messaging app, even right now many citizens call still use the app using a simple method using a Virtual Private Network $(\mathrm{VPN}){ }^{39}$

Second, over the transition from AlQaeda to ISIS attacks in Indonesia, the police force is often considered as the main targets by ISIS supporters, mainly due to the reason of the high achievement of Densus 88 (Indonesia's Counter Terrorism Police Unit) in capturing or eliminating terrorist suspects over the past decade. One of the strategy used is to let police personnel mingle with terrorist captives, as many of the personnel are devout Muslims, they would take prayers together and conversed afterwards. This would denounce the myth ISIS has been building towards police forces that they are working together with nonbelievers against Islam. The enhancement of this strategy came from many intellectual and moderately religious institutions declaring their support including NU and Muhammadiyah as the two largest moderate Islam organization in

38 Muhammad Ikhsan Mahar, "Terorisme dan Pemblokiran Telegram”, Kompas, 18 July 2017.

39 Safrin La Batu, "Blocking of Telegram deemed ineffective”, Jakarta Post, 18 July 2017
Indonesia. Public and private universities also voiced their support, such as the Antiradicalism and Terrorism Declaration made by 44 universities in West Sumatra.

Third, the ban of radical Muslim organization such as Hizbut Tahrir Indonesia (HTI) in recent news. HTI is known for its vocal support of the inducting Sharia law to the nation's ideology, essentially in line with ISIS's goal of creating a caliphate. Stated by Wiranto, Indonesia's Minister for Political, Legal, and Security Affairs, "The activities of HTI strongly indicate that they have conflict with the Pancasila and the constitution. ${ }^{40}$ HTI is one of the few radical Muslim organization that brazenly oppose the idea of Pancasila and tolerance, the other including Front Pembela Islam (FPI).

\section{Conclusion}

From Al-Qaeda to ISIS, these two group share the spotlight of being a global terrorism threat almost over the past two decades ago. Although both share the same Sunni hardline Salafist ideology, they differ greatly in other important aspects. First is their goal in mind, Al-Qaeda's goal is based on fighting off the west that they consider as nonbeliever or kafir while ISIS's narrative expanded it even further with the creation of a caliphate. Second is their method of recruiting foreign fighters and how they coordinate their attack in other countries. While Al-Qaeda takes a more careful approach of recruiting foreign fighters that have well-educated background, they have not been very successful in infiltrating their fighters to western countries. ISIS on the other hand manage to do so because of its openness in recruiting almost everyone without a background check, this strategy has resulted in

\footnotetext{
${ }^{40}$ Davies and Robert Birsel, "Indonesia to disband hardline Islamist group Hizb ut-Tahrir", Reuters, last modified 8 May 2017, accessed 27 July 2017 http://www.reuters.com/article/us-indonesiaislamists-idUSKBN184159
} 
foreign fighters that were recruited from the western countries they sought to attack, given combat training, and returned to their home country as sleeper cells.

This is also related to the third point of how Al-Qaeda and ISIS spread their ideology. Al-Qaeda prefer encrypted websites and connection with trusted sympathizers whom they can email their propaganda materials. Meanwhile ISIS employ a more open tactic that heavily rely on current social media, crowdsourcing their propaganda material so that anyone especially those who were deeply troubled can use ISIS's ideology and craft it for their own cause with ISIS as its brand. ISIS's strategy of employing foreign fighters and spreading its propaganda through social media proves to be successful, where multiple attacks by lone wolf attackers that would later be identified as ISIS supporters occurred multiple time in U.S and Europe.

However, the loss that ISIS is experiencing in Iraq and Syria creates the possibility of creating another caliphate in Southeast Asia, as it is a region with major Muslim population and history of radicalism particularly present in Indonesia and Philippines. As of May 2017, a coalition of local terrorist groups in Philippines declared their allegiance to ISIS and captured the city of Marawi, in the Muslim majority island of Mindanao. This turn of event can impact how ISIS operates in Indonesia, as the country with the highest number of Muslims.

Threading on further, Al-Qaeda in Indonesia, known as Jemaah Islamiyah (JI) has also pledged his support to ISIS. Evolving the method of operation from Bali and Australian Embassy Bombings that were carefully planned and span few years to sporadic attacks not by ISIS fighters but lone supporters over the span of one year, with the help of social media such as Telegram. The radicalization process by ISIS has also reached female Indonesian migrant workers abroad in Hongkong, Taiwan, and Singapore with ISIS's social media strategy playing a huge part. There were three counter strategy that the Indonesian government employed, first the government has blocked eleven Telegram domains to disrupt communication and spread of ISIS propaganda. Although deemed ineffective by analysts, it provides a quick and temporary solution specially to minimize the propaganda effect of ISIS's victory in Marawi. But the government should not just block social media app that ISIS use, they should utilize it for deradicalization process as well.

Second, as moderate Islamic institutions such as NU and Muhammadiyah join the deradicalization effort, they must utilize social media similar to how ISIS use it as well. This is to ensure that the deradicalization process is not only applied to level of captured terrorist suspects or students from an extremist madrasah, but the effort resonates through the whole social media and internet to help minimize the chance of lone wolf attacks to occur again. It should also assist in deradicalizing Indonesians that are outside the country, such as the migrant workers case mentioned before. The government can utilize the media by providing stories of refugees from ISIS-held territories, or show a speech by a deradicalized terrorist member to tell the truth about ISIS.

Third, the disbandment of HTI is a positive effort to reduce the radicalization process in mass effect. But it can impose the problem of HTI members turning to a more extremist attitude as they are unable to voice their ideas through legitimate and peaceful actions, the momentum can be used by ISIS in accordance with its Philippines caliphate campaign. Supporters of ISIS may join the battle in Marawi and return more dangerous as they have acquired combat experience. Indonesia is facing a new level of threat from ISIS based on the events of Marawi, although the government has taken first measures to halt the threat, it must also consider the strategy to counter the radicalization process by ISIS 
through the means of social media in the long run.

\section{References}

\section{Books:}

Scott Atran, "The Role of Radical Madrasahs in Terrorism: The Indonesian Case", in Conflict, Community, and Criminality in Southeast Asia and Australia, ed. Arnaud De Borchgrave et, al, Washington: CSIS, 2009.

\section{Newspaper:}

Safrin La Batu, "Blocking of Telegram deemed ineffective”, Jakarta Post, 18 July 2017

Muhammad Ikhsan Mahar, "Terorisme dan Pemblokiran Telegram”, Kompas, 18 July 2017.

\section{Online Articles:}

Agence France-Presse, "Timeline: Moro history in the southern Philippines", $A B S-C B N$, last modified 28 March 2014, accessed 20 July 2017 http://news.abscbn.com/nation/regions/03/27/14/timelin e-moro-history-southern-philippines

BBC News, "Islamic State and the crisis in Iraq and Syria in maps", $B B C$, last modified January 2016, accessed 18 July 2017 http://www.bbc.com/news/worldmiddle-east-27838034

Brendan I. Koerner, "Why ISIS Is Winning the Social Media War",WIRED, last modified April 2016, accessed 15 July 2017

https://www.wired.com/2016/03/isiswinning-social-media-war-heresbeat/\#slide-x

Clint Watts, “Al Qaeda Loses Touch”, Foreign Affairs, last modified 4 February 2015, $\begin{array}{llll}\text { accessed } & 11 \quad \text { July } & 2017\end{array}$ https://www.foreignaffairs.com/articles/ middle-east/2015-02-04/al-qaeda-losestouch

Clint Watts, "Why ISIS Beats al Qaeda in Europe", Foreign Affairs, last modified 4 April 2016, accessed 11 July 2017 https://www.foreignaffairs.com/articles/ 2016-04-04/why-isis-beats-al-qaedaeurope

Davies and Robert Birsel, "Indonesia to disband hardline Islamist group Hizb utTahrir", Reuters, last modified 8 May 2017, accessed 27 July 2017 http://www.reuters.com/article/usindonesia-islamists-idUSKBN184159

Faith Karimi, "San Bernardino shooters 'supporters' of ISIS, terror group says", CNN, last modified 6 December 2015, accessed $15 \quad$ July 2017 http://edition.cnn.com/2015/12/05/us/sa n-bernardino-shooting/index.html

Gadi Markitan, Arkhelaus Wisnu," Begini Bachrun Naim Manfaatkan Telegram Untuk Merancang Teror", Tempo.co, last modified 15 July 2017, accessed 27 Jul.

17."https://nasional.tempo.co/read/news/ 2017/07/15/063891613/begini-bachrunnaim-manfaatkan-telegram-untukmerancang-teror

Institute for Policy Analysis of Conflict, "MARAWI, THE "EAST ASIA WILAYAH" AND INDONESIA", last modified 21 July 2017, accessed 26 July 2017

http://file.understandingconflict.org/file/ 2017/07/IPAC_Report_38.pdf

Jonathan Head, "Maute rebel group: A rising threat to Philippines", last modified 31 May 2017, accessed 27 July 2017 http://www.bbc.com/news/world-asia40103602

Karl Vick, “Al-Qaeda Group Claims Responsibility for Paris Terror 
Attack",TIME, last modified 10 January 2015, accessed 18 July 2017 http://time.com/3661650/charlie-hebdoparis-terror-attack-al-qaeda/

Hassan M. Fattah, "Al Qaeda Increasingly Reliant on Media", New York Times, last modified 30 April 2006, accessed 15 July 2017 http://www.nytimes.com/2006/09/30/wo rld/30jordan.html

M.J Kirdar "Al Qaeda in Iraq", CSIS, June 2011, accessed 8 July 2017, https://csisprod.s3.amazonaws.com/s3fspublic/legacy_files/files/publication/110 614_Kirdar_AlQaedaIraq_Web.pdf

Nava Nuraniyah, "Migrant Maids and Nannies for Jihad", New York Times, last modified 18 July 2017, accessed 27 2017

https://mobile.nytimes.com/2017/07/18/ opinion/isis-jihad-indonesia-migrantworkers.html?smid=twshare\&referer=https $\% 3 \mathrm{~A} \% 2 \mathrm{~F} \% 2 \mathrm{Ft} . \mathrm{co} \%$ 2F2mysbb3P4K

Pamela Engel, "This map shows how much territory ISIS has lost this year", Business Insider, last modified 21 December 2015, accessed 18 July 2017, http://www.businessinsider.sg/maphow-much-territory-isis-lost-2015$12 / ? \mathrm{r}=\mathrm{US} \& \mathrm{IR}=\mathrm{T}$.

Ryan Rosauro, "MILF willing to help end Marawi crisis", last modified 28 June 2017, accessed 27 July 2017, http://newsinfo.inquirer.net/909394/milf -willing-to-play-role-to-resolve-marawicrisis-if

Rezki Alvionitasari, Imam Hamdi, Dewi Suci, "Police Clamps Down on Terror Ring Linked to Bandung Bomber", Tempo.co, last modified 1 March, accessed 27 July 2017 2017 , https://en.tempo.co/read/news/2017/03/0
1/055851350/Police-Clamps-Down-onTerror-Ring-Linked-to-BandungBomber

Rowan Scarborough, "Islamic State using app to broadcast terror instructions, propaganda", Washington Times, last modified January 8 2017, accessed 18 July

2017 http://www.washingtontimes.com/news/ 2017/jan/8/isis-using-telegram-app-tobroadcast-terror-instru/

Sandy Indra Pertama, "Tentang Bahrun Naim yang Diduga Sosok Pengendali”, $C N N$ Indonesia, last modified 14 January 2016, accessed 27 July 2017, https://www.cnnindonesia.com/nasional/ 20160114191812-12-104414/tentangbahrun-naim-yang-diduga-sosokpengendali/

The Associated Press, "Indonesian Police Arrest 4 Near Jakarta as Terrorist Plot Is Foiled", New York Times, last modified 10 December 2016, accessed $27 \mathrm{Jul}$ 2017

https://www.nytimes.com/2016/12/10/w orld/asia/indonesian-police-arrest-4near-jakarta-as-terrorist-plot-isfoiled.html

Tony Cartalucci, "NATO Using Al Qaeda "Rat Lines" to Flood Syria With Foreign Terrorists", Global Research last modified 26 October 2012, accessed 11 July 2017 http://www.globalresearch.ca/natousing-al-qaeda-rat-lines-to-flood-syriawith-foreign-terrorists/5309573

Zachary Laub , "The Islamic State", Council on Foreign Relations, last updated 10 August 2016, accessed 11 July 2017, https://www.cfr.org/backgrounder/islami c-state.

Website: 
158 Naufal Armia Arifin The Evolution Of ISIS In Indonesia With Regards To Its Social Media Strategy

"Dabiq, 13 ${ }^{\text {th }}$ Issue", last modified 2015, http://clarionproject.org/factsheets-

files/Issue-13-the-rafidah.pdf 